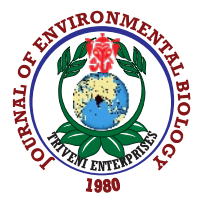

\title{
Impact and prospects of water conservation on fish habitat and advances of ecobiology operation in Yangtze River, China: A review
}

\author{
J. Zhang*, Y. Zhang, Y. Feng, R. Yan, Y. Shi,Y. Zhang and Y. Ji \\ College of Water Conservancy and Ecological Engineering, Nanchang Institute of Technology, Nanchang-330 099, China \\ *Corresponding Author Email : 18502573@qq.com
}

\section{Abstract}

Yangtze River, the longest river in Asia, provides 40 percent of freshwater in China and plays an important role in ecological biodiversity. However, this ecosystem has been deteriorated by the continuously construction of reservoirs and hydropower stations. Many investigations have been carried for the biodiversity, hydrological indicators, and species distribution along Yangtze River caused by dam construction.

As a result, the ecological operation has been gradually applied to mitigate the negative effects of water conservancy projects. In order to well know recent advances in the study of fish habitat in the Yangtze River Basin, 424 original papers published from 2000 to 2020 using bibliometrics were compiled in this research to analyze the developing trends including topics, data, and research status.

The results of literature statistics showed that the related research fields on the effects of the reservoir on hydrological indicators mainly focused on negative impact caused by hydrological changes, water temperature effect, and sediment variation. In the studies on the habitats of fish, the four major Chinese carps and Chinese sturgeon were the main objects of concern, in which multiobjective joint operation, cascade reservoir operation, and model coupling have been widely adapted.

Key words: Biodiversity, China, Ecological Operation, Fish communities, Yangtze River

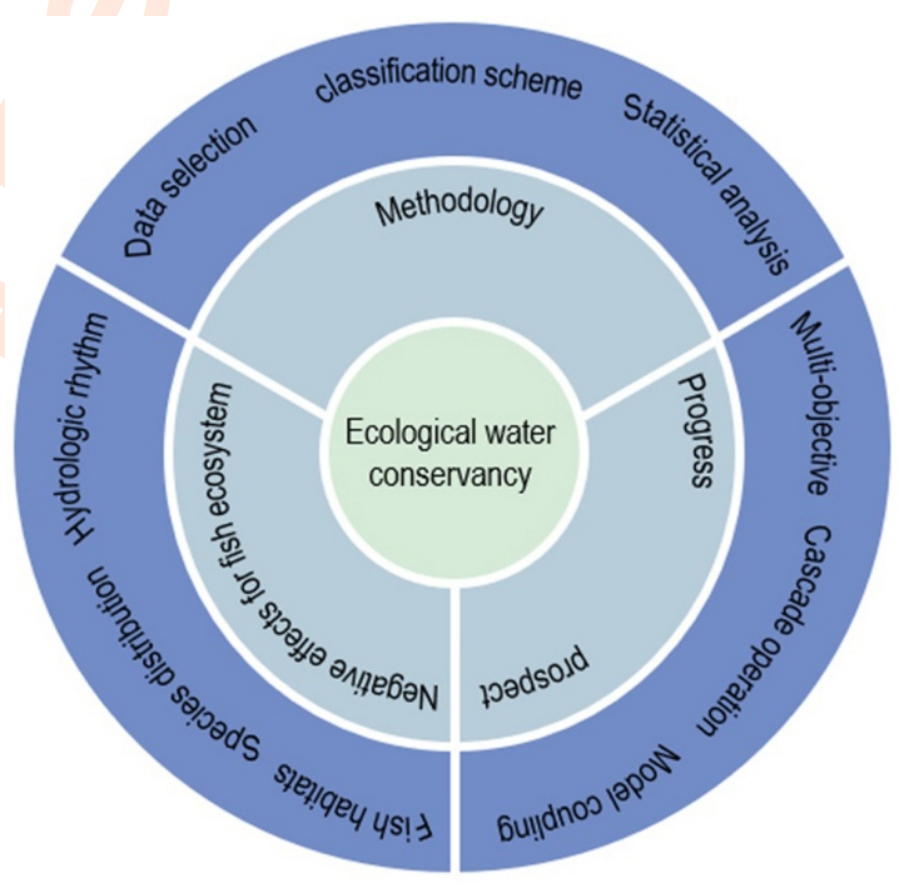




\section{Introduction}

The formation of land terrain is closely related to geological activities and geographical position, which determines the regional climate, rainfall, vegetation, and local ecosystems. (Houze, 2012; Wang et al., 2013; Zhao, 2012). The topography of terrain in China looks like a three-step ladder where the western region is covered with continuous high mountains and the eastern region is full of plain. Accounting for about 20 percent of the nation's total areas, the Yangtze River is the longest river in China with a total length of $6,300 \mathrm{~km}$ and a basin area of $180 \mathrm{sq} \mathrm{km} \mathrm{(Lu,} \mathrm{2018).} \mathrm{It} \mathrm{originates} \mathrm{from} \mathrm{the}$ Qinghai-Tibet Plateau and flows through 11 provinces, crossing different landforms and flowing eastward into the East China Sea (Zhang et al., 2019). Besides, there are thousands of tributaries and freshwater lakes in the Yangtze River basin. With warm climate and plenty rainfall, the Yangtze Basin accounts for 40 percent of China's freshwater resources and has an irreplaceable ecological function (Deng et al., 2014).

However, the Yangtze River has also seen the rapid development of numerous water projects. By now, more than 50,000 reservoirs and nearly 20,000 hydropower stations have been built to control flood, generate power and transportation needs (Chen et al., 2016; Wu et al., 2019). These projects have artificially changed the hydrodynamic conditions of the water flow and caused a series of ecological and environmental problems such as destruction of aquatic biological resources, shrinking of wetlands, and loss of biological habitats (He et al., 2010; Mao et al., 2005). In particular, the impact of these water conservation projects on the water quality of the Yangtze River has attracted international attention (Zhuo et al., 2017).Many studies have been devoted to the water quality assessment in the Yangtze River and many methods have been applied such as single factor method (Lv and Mi, 2011),TOPSIS (Technique for order preference by similarity to an ideal solution) model (Wang et al., 2017), multiple comparative test and contrast analysis (Li et al., 2017). Furthermore, the variation range of water flow is limited to a small range and the natural environment on which river life depends tends to be monotonous, which as further led to ecosystem degradation (Wu et al., 2020). Some of the effects of reduced sediment concentration, delayed temperature effects, and changes in the relationship between rivers and lakes are still being assessed (Bing et al., 2019; Gao et al., 2020).

Therefore, much attention has been focused on the ecological effects and corresponding mitigation measures caused by water conservancy projects (Chen et al., 2015; Ji et al., 2014). Referring to country's research progress on ecological protection of river management, studies over the past twenty years have provided important information on the method to ameliorate the ecological environment and improve the ecological service function (Guisan and Thuiller, 2005). Several attempts have been made to analyze the minimum water demand to maintain the dynamic stability of habitats and biological communities (Palmer et al., 2010; Poff and
Zimmerman, 2010). Significant results have been achieved on pollutant transport (Ji et al., 2017), environmental pollution monitoring in rivers and lakes (Ji et al., 2010), environmental behavior of pollutants (zhang et al., 2018), aquatic ecological risk under hydrodynamic interaction (Ji et al., 2014; Ji et al., 2017(a); Ji et al., 2017(b)), and model simulations (Ji et al., 2007).

In recent years, several studies have focused on reservoirs ecological operation, where fish including Four Major Chinese Carp (FMCC) and Chinese sturgeon (CS) have been usually used as a target for operation (Dai et al., 2017; Hu et al., 2008;). As top communities in the aquatic ecosystem, fish distribution is more conducive to analyze the effect of multiobjective joint operation, cascade reservoir operation, and model coupling (Park et al., 2006). Habitat fragmentation that results from the "barrier effect" is one of the most serious effects (Fu et al., 2003). Since 2011, 11 ecological operation experiments have been carried to evaluate the ecological effect about restoring the fish population caused by Three Gorges Reservoir (TGR). However, there were still no enough public papers to reveal the association between reservoirs' ecological operation and fish ecosystem in the Yangtze River Basin (Tao etal., 2012; Qiao et al., 2006).

In this study, the classification methods (Ji et al., 2020) were adopted to select relevant journals and databases. Related articles, books, and diploma thesis were screened by using "Yangtze River Basin", "Ecological system", "Fish", and "Ecological operation" in titles, abstracts, and keywords. Altogether, 424 original papers published from 2000 to 2020 using bibliometrics has been compiled in this research to analyze the fish distribution characteristics and the advances of ecological operation in the Yangtze River Basin. The time and categories distribution of 424 publications are shown in Fig. 1. The articles are related to fish ecosystems within hydrological factors, habitats, and species distribution. In relating with the ecological operation, these articles can be divided into cascade operation, Multi-objective operation, and Theoretical basis. In this review, the impact of water conservation on fish along the Yangtze River Basin is provided. Meanwhile, the advances and prominent fields are presented to clarify whether the direction were suitable for future study on ecological operation.

Impact of water conservation on fish ecosystem: Hydrologic rhythm change is one of the most serious effects of after construction of water conservancy project, which would inevitably lead to habitat fragmentation of fish habits (Gillette et al., 2005; Morita and Yamamoto, 2002). Based on statistical results, hydrological rhythm, species distribution, and habitats are topics of concern.

Impact of water conservation on hydrologic rhythm associated with fish: Constructions of dams unavoidably change river continuity, inducing alterations in river flow, water temperature, and sediment regimes (Walling and Fang, 2003; Ye et al., 2011). In the last few decades, a large number of reservoirs, such as Gezhouba Reservoir and Three Gorges Reservoir, have 
been built along the Yangtze River basin, which has inevitably changed the natural runoff characteristics(Black et al., 2005). The hydrological information transmission can help to analyze the change rule of hydrological rhythm (Ji et al., 2012). Fig. 2 demonstrates long-term historical hydrological data including before cascade dams (1949-1998), during cascade dams (19992014), and after cascade dams (2008-2014) from the Yichang and Datong station (Duan et al., 2016). There had been an overall decline in flow from July to November and a modest increase from January to May, with the biggest drop in September and October since the dam began operating. These changes in hydrological flow will inevitably affect the reproduction and growth of fish that produce drifting eggs, such as reducing the survival rate, no enough drifting distance (Chong et al., 2006).

Dam construction would also increase water depth and cause water temperature stratification in the reservoir area. As a result, the low temperature water discharged from the bottom negatively affects the oviposition signal of water-sensitive fish, and ultimately affect the number and quality of oviposition (Caissie, 2006; Ellis and Jones, 2013). Published articles indicate that the water temperature in winter and early spring is highly related to the gonad development of breeding population (Jury, 2012; Yu et al., 2019), reported a significant descending trend for FMCC and CS after TGR operation. Fig. 3 illustrated monthly mean water temperature distribution characteristics before Three Gorges Reservoir construction from 1982 to 2003 and post Three Gorges Reservoir operation (Zhang et al., 2019).

Low temperature, cumulative temperature, and relative temperature difference might delay gonad development of fish and spawning of Chinese sturgeon and Four Major Chinese Carp (Yu et al., 2019). Dam construction has also altered the sediment regimes and influenced river geomorphology, morphology, ecosystem health, and stability (Chang et al., 2017; Wu et al.,
2016). As presented in Fig. 4, Data from Cuntan, Yichang, Hankou, and Datong hydrological stations indicates that sediment load from these stations decreased significantly and showed a similar trend post Three Gorges Reservoir operation. Compared with the impact of Three Gorges Reservoir, the impact of sediment load at Cuntan, Yichang, Hankou, and Datong hydrological stations caused by Gezhouba Reservoir was much smaller. Before the construction of Three Gorges Reservoir, annual sediment loads at Yichang were higher than those at Cuntan, which resulted in considerable sediment trapping by the Gezhouba Reservoir. Besides, annual sediment loads at Hankou and Datong were less affected by the Gezhouba Reservoir because of long distance and out of backwater range (Li et al., 2011).

Impact of water conservation on species distribution: In Yangtze River Basin, 416 fish species and subspecies belonging to 16 orders have been recorded with the most species belonging to order Cypriniformes, with a total of 362 species and subspecies spending their lives entirely in freshwater, and 11 migratory fishes including 8 anadromous species (Humphrey et al., 2010). The remaining 43 species mainly live in brackish water of the estuary with a wide range of salt tolerance, and moved regularly between coasts and estuary (Fu et al., 2003). As shown in Fig. 5 , there were 162 endemic species which occupied $39.4 \%$ of the total number of fishes (Ye et al., 2014).

Among them, species richness and endemic species were mostly recorded at the upper reach (Fu et al., 2004). Fish in this area have adapted to rapid current and inhabit the underlayer, and some of them including families of Homalopteridae and Sisoridae live by the stones of river bed. The number of endemic fish species in the middle and lower reaches was significantly lower than that in the upper reaches which might be due to pollution and river barriers (Park et al., 2003). As illustrated in Fig. 6, 65 fish species from the Yangtze

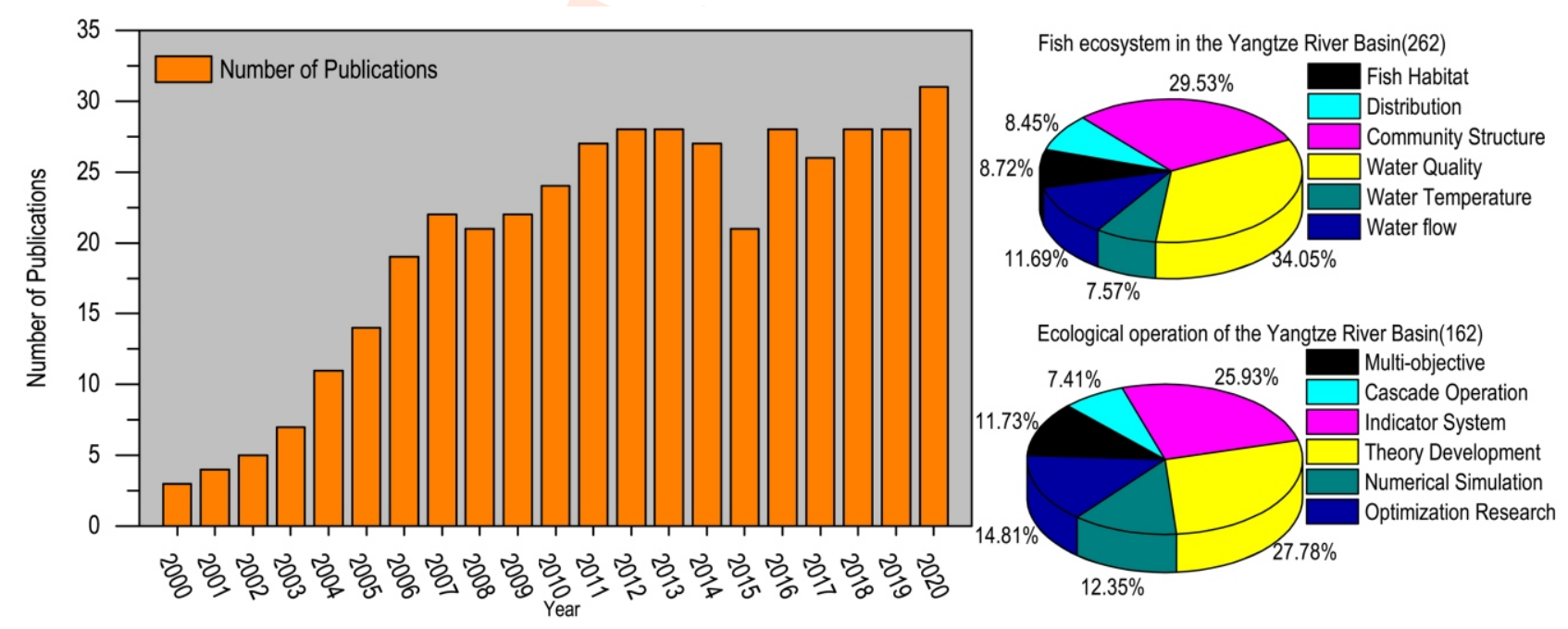

Fig. 1: Time and categories distribution of publication. 

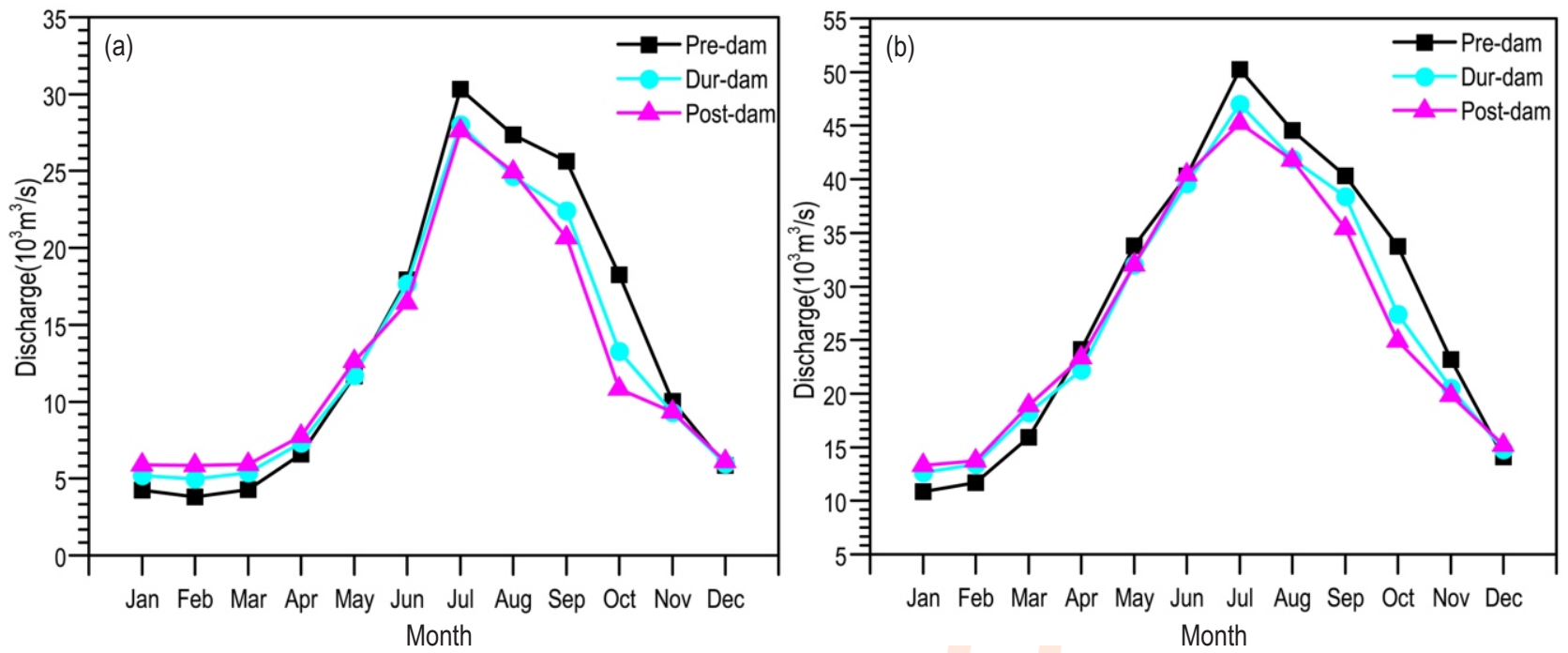

Fig. 2: Mean monthly discharge at Yichang (a) and Datong (b); Pre-dam: The long-term historical hydrological data including before cascade dams; Durdam: The long-term historical hydrological data including during cascade dams and Post-dam: The long-term historical hydrological data including after cascade dams.

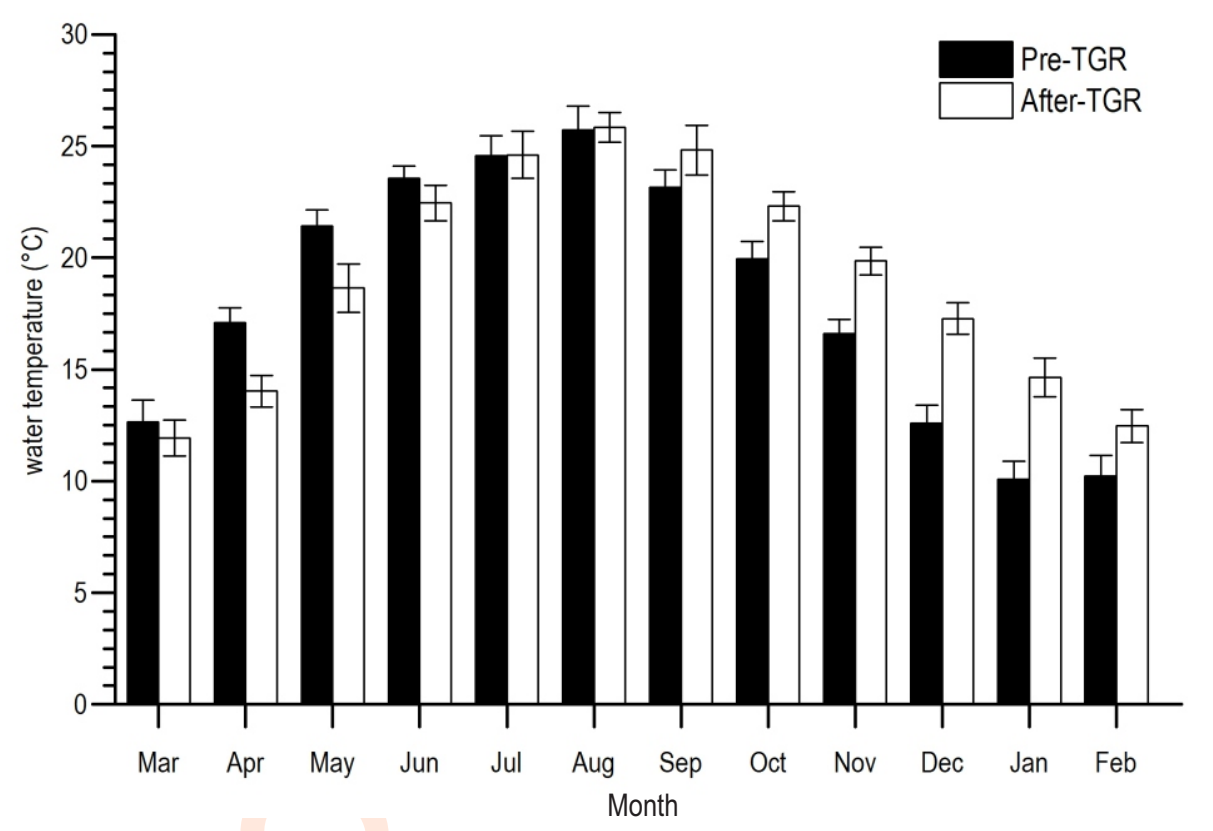

Fig. 3: Mean monthly water temperature distribution before and after operation of TGR; Pre-TGR: Monthly mean water temperature distribution characteristics before TGR construction and After-TGR: Monthly mean water temperature distribution characteristicsafter TGR operation.

River Basin are now listed in the China Species Red List which is classified into five threatened categories (Wang and Xie, 2009). In the upper reach with a large river gradient and abundant hydropower resources, Anabarilius polylepis and Schizothorax parvus are listed as extinct in the wild, Anabarilius liu as extinct subspecies and Megalobrama elongata,
Schizothorax longibarbus and Leiocassislongibarbus as critically endangered species since 1980 due to over-fishing, developing industries, mining enterprises and water pollution (Xie, 2017). Among these factors, hydrological alterations and river barriers caused by water conservancy projects are threatening for fish biodiversity (Huang and Li, 2016). Statistics 


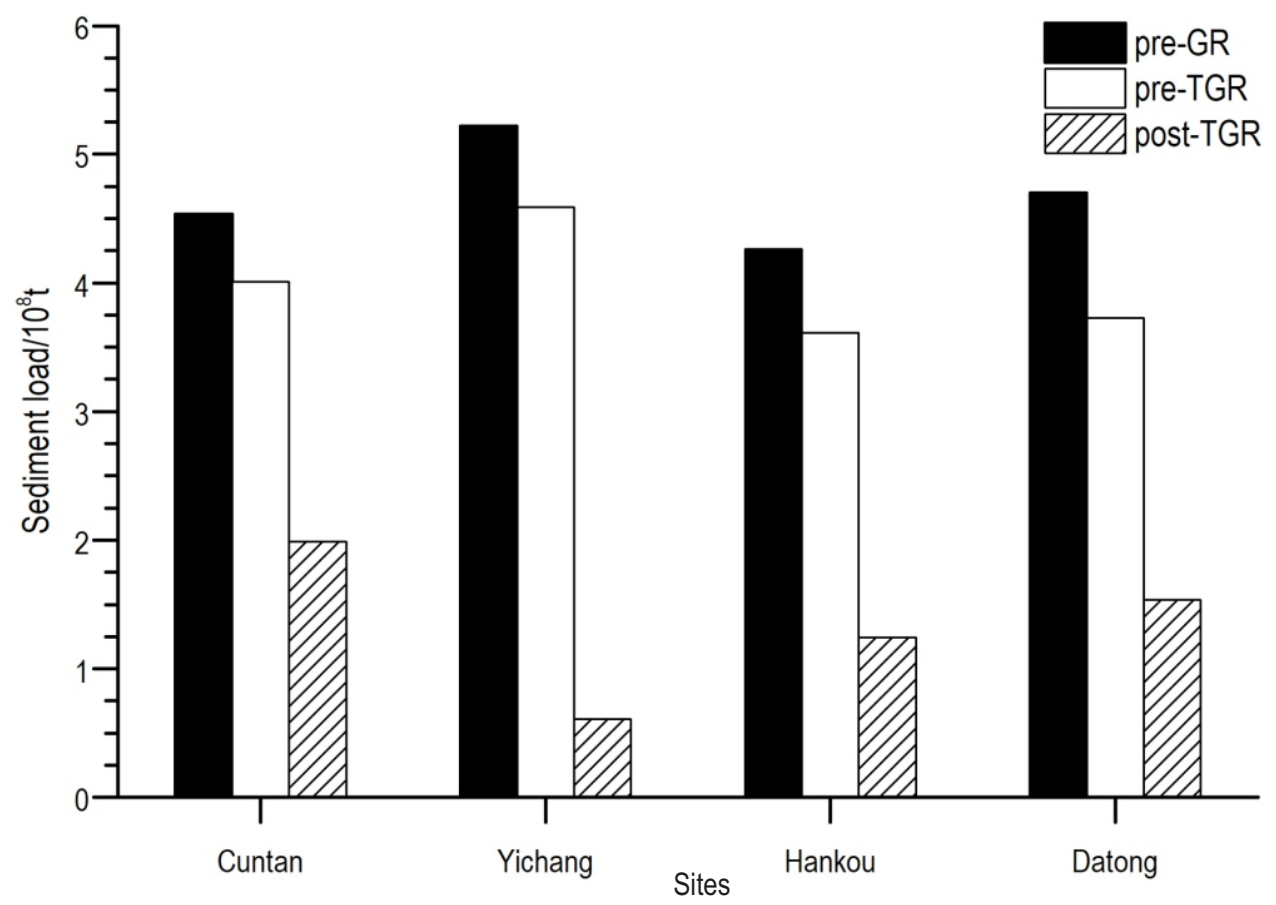

Fig. 4: Mean annual sediment load in different sub-periods and the proportion of sediment load; Pre-GR: Mean annual sediment load including before GR construction; Pre-TGR: Mean annual sediment load including before TGR construction and Post-TGR: Mean annual sediment load including after TGR construction.

data show a total 127 cascade power stations listed on building plan in the upper reaches including Jinsha, Yalong, Dadu, Minjiang, Jialing, and Wujiang River. There are 22 steps power stations distributed along the Yalong River, which would completely change the hydrodynamic, hydro-chemical conditions in these areas and destroy the habitat of original aquatic ecosystem. Indigenous fish species in the Yalong River was mainly composed by Schizothorax which had been adapted to rapid water flow in the long course of historical evolution (Lin, 2019). However, the indigenous fish were forced to migrate to tail and tributaries after the operation of Ertan Reservoir.

As listed in Table 1, the weight percentage of indigenous fish decreased significantly, and decreased from $71.9 \%$ before the reservoir construction to $16.0 \%$ after the reservoir construction (Jiang et al., 2007). In the middle and lower reach of Yangtze River with high density of industry and agriculture, water pollution not only reduced fish habit at through direct effects, but also caused negative impacts on plankton and benthos, resulting in decrease in the abundance of natural fish stocks (Huang and Xie, 1996; Ye, 2007). Furthermore, the complex lacustrineriverine network in the middle and lower reaches of the Yangtze River was destroyed in 1950 to some extent that prevented fish entering lakes for food, growth or spawn, and returning to the river or the sea (Liu and Wang, 2010). The perusal of data from Table 2 shows that Dongting Lake that river-lake disconnection reduced fish diversity of Yangtze lakes by $38.1 \%$.
Impact of water conservation on fish habitats: A certain amount of water flow, complete river bed and river bank structure, full nutrients are prerequisite for survival and reproduction of fish. However, conservancy projects operation would change hydrologic process, cut off the connectivity of rivers, and lead to fragmentation of river system (Aarts et al., 2010; Shen et al., 2018). Table 3 shows the reproductive characteristics and spatial distribution characteristics of FMCC (black carp, grass carp, silver carp, and big-head carp) and CS (Liu et al., 1997; Yu, 2002). These fishes are accustomed to migrate between fresh and saltwater, and require migration over long distances within freshwater in the Yangtze River basin.

As listed in Table 3, the middle reach of the Yangtze River, which was $898 \mathrm{~km}$ long with $680000 \mathrm{sq} \mathrm{km}$ drainage area, was the main habitat for Four Major Chinese Carp and Chinese sturgeon. Before the operation of GR, there were 36 spawning grounds along the middle reaches of the Yangtze River, ranging from Chongqing to Pengze. However, the spawning area of FMCC and CS gradually reduced, and the number of fish reduced significantly also since dam, was constructed which changed the location and scale of spawning along the Yichang River section. Furthermore, the submerged area increased and the water level raised since the constructions of TGR, which further affected fish habitats with low flow, low temperature water (Fan et al., 2010; Yi et al., 2010). As a large anadromous fish species appear in the main stream of the Yangtze River, the spawning grounds of CS 


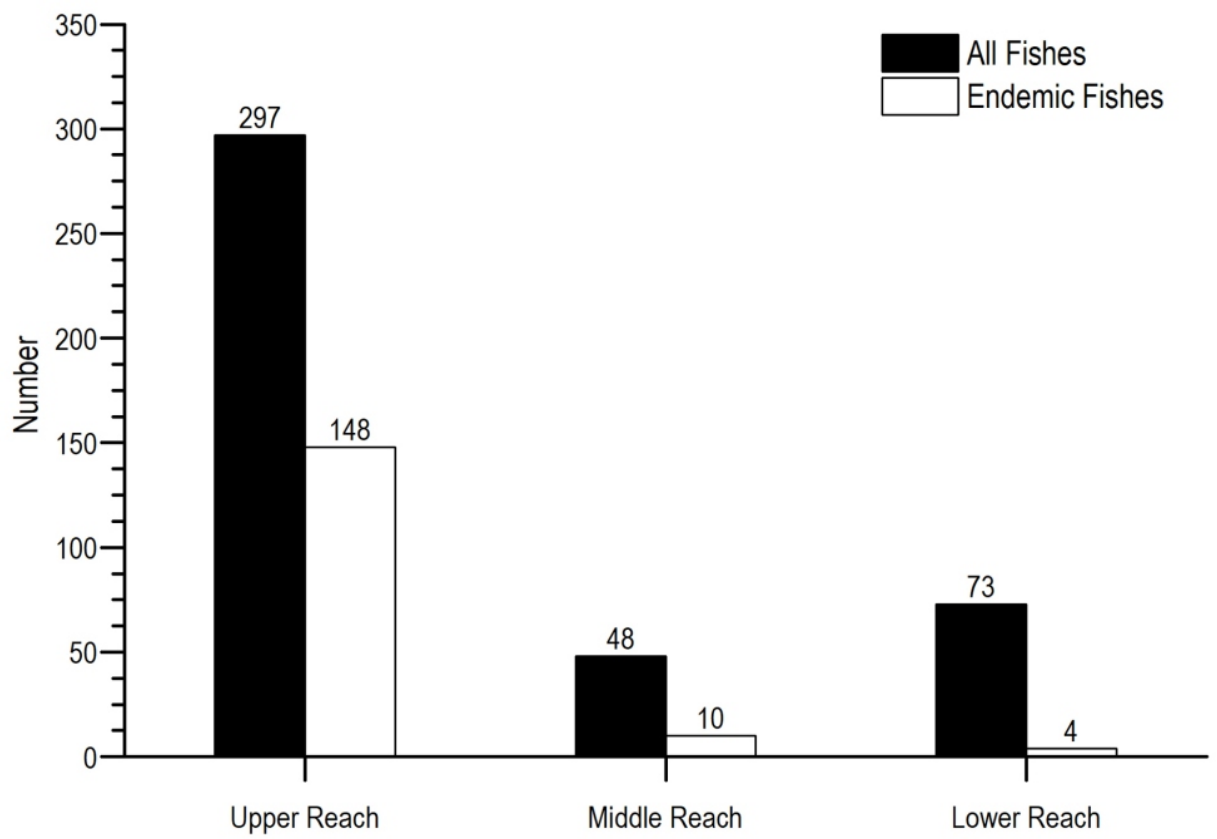

Fig. 5: Spatial distribution of fishes in the Yangtze River Basin.

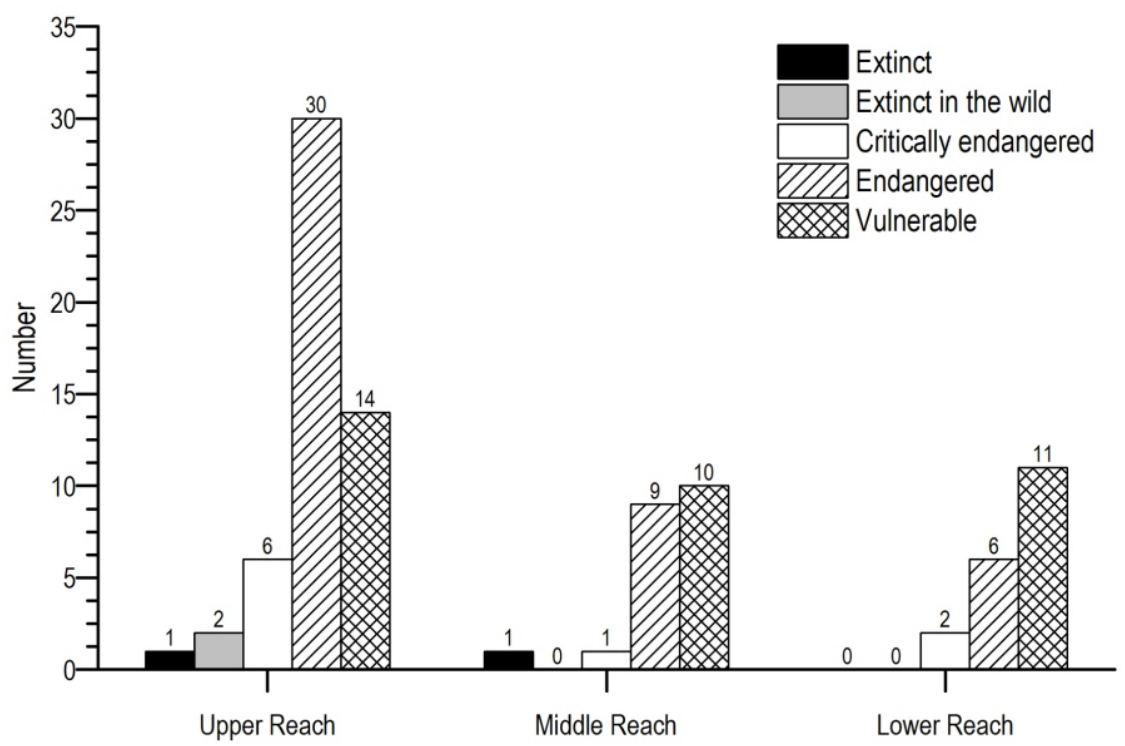

Fig. 6: Threatened status of fishes in the Yangtze River Basin(Species Red List of China).

were mainly distributed in the lower reaches of the Jinsha River to the upper reaches of the Yangtze River in Qingshan (Wei et al., 1997). Constraint by two mountainous sides, the water surface in these areas was usually narrow with fast water flow, and the riverbed was mainly covered with pebbles and gravel, which were the best survival and reproduction conditions for Chinese sturgeon (Du et al., 2011; Kynard et al., 1995). Post construction of Gezhouba Reservoir, the Chinese sturgeon was blocked down the dam, and the spawning ground was reduced 40 times distributing along the Yichang River section (Yang et al., 2006; Wang et al., 2013). TGR operation further affected the survival and reproduction of CS with flow control during the flood period, which resulted in the reduction of actual water surface of the spawning ground under the dam. 
Table 1: Fish composition for pre-post periods of Ertan Reservoir operation in the Yalong River, China

\begin{tabular}{lllll}
\hline & \multicolumn{2}{c}{ Before reservoiroperation } & \multicolumn{2}{c}{ After reservoir operation } \\
\cline { 2 - 5 } Fishing composition & Weight $(\mathbf{k g})$ & Relative biomass $(\%)$ & Weight $(\mathbf{k g})$ & Relative biomass (\%) \\
\hline Schizothorax & 151.8 & 71.9 & 39.7 & 16.0 \\
Coreius guichenoti & 2.6 & 1.2 & 6.5 & 2.6 \\
Other fish & 11.5 & 5.3 & 1.3 & 0.5 \\
\hline
\end{tabular}

*Research period: The period before the reservoir operation was from 1992 to 1994 and from 1996 to 1998 . The period after the reservoir operation was from 2002 to 2004.

Table 2: Fish composition for the river connected and disconnected periods in Dongting Lake, China

\begin{tabular}{lllll}
\hline & \multicolumn{2}{c}{ River-connected lakes } & \multicolumn{2}{c}{ River-disconnected lakes } \\
\cline { 2 - 5 } & Richness & Percentage (\%) & Richness & Percentage (\%) \\
\hline Lake resident & 60 & 51.7 & 45 & 56.3 \\
Riverine species & 36 & 31.0 & 23 & 28.8 \\
River-lake migratory & 15 & 12.9 & 11 & 13.8 \\
River-sea migratory & 5 & 4.3 & 1 & 1.3 \\
\hline
\end{tabular}

*Research period: The period for the river connected lakes was from 1950 to 1990. The period for the river disconnected lakes was from 1990 to 2000.

\section{Progress and Prospect}

Progress of ecological operation: With the increasing pressure for the aquatic habitat in the downstream area, reservoir regulation considering ecological impacts has attracted much attention (Chang et al., 2010; Wang et al., 2015). In the past few years, attempts have been made to treat river ecological protection as an important component of multi-reservoir operation decisions, which required taking power production, flood control, navigation, and environmental protection as equal goals (Guo et al., 2011; He et al., 2018; Jager and Smith, 2010;). Since 2011, the ecological control experiments around the TGR have been organized to promote the natural breed of FMCC for seven consecutive years. However, FMCC and CS communities were still the main indicators for impact of hydrological change, which could not guarantee the reproduction and development of other species in the aquatic ecosystem.

In addition, different sections of the Yangtze River Basin had different riverbed geomorphic features due to the influence of topography, which required that the ecological operation of reservoirs should be adapted for local conditions. At present, most of the reservoir ecological management only considered the ecological impact of a single reservoir, such as Gezhouba Reservoir and Three Gorges Reservoir (Krawczyk et al., 2013; Yang et al., 2007). However, the impact of cascade reservoir regulation on the ecological system by more reservoirs planned or under operation has not been studied intensively (Ma et al., 2018; Wang et al., 2012). Because of the serious negative ecological impact of reservoir on fish habitat, the reservoir regulation in the Yangtze River has started to develop from a single project to cascade reservoir operation. However, multi objective optimization, ecological flow calculation, public participation, supervision responsibility, interbasin diversion are still research hotspots in this field. Mathematical models like SWAT, MIKE are mainly used to simulate the impact of hydropower cascade development. With the rapid development of science and technology, the mathematical models of different algorithms has been widely concerned and applied (Shen et al., 2012; Wang et al., 2018). As summarized in Table 4, the researches on ecological operation in the Yangtze River Basin mainly focused on model and algorithm. Different kinds of hydrodynamic mathematical model had been established with different algorithm to provide an access for the protection of FMCC and CS by ecological operation of the reservoir. However, research on the response process of different ecosystem types under water conservancy projectecological operation is still lacking.

Prospect of reservoir ecological operation: With the understanding of different ecosystems, the role of different indicator species in the aquatic ecosystem has been further studied, and benthic animals, phytoplankton, zooplankton, higher aquatic plants have gradually been included in the multiobjective ecological operation (Hakimi-Asiabar et al., 2010; Yi et al., 2020). Ecological hydrological index system consisting of hydrological change index, change range method, and environmental flow component has been mentioned to evaluate the effect of the behavior of indicator species (Mathews and Richter, 2010). It was obvious that versatility and feasibility of hydrological factors would be the research hotspot of reservoir operation in future. In addition, the conflicts of existing multiobjective operational modes, such as ecological protection, irrigation, flooding control, etc., made it difficult to achieve the optimal goal, and form an absolute optimal plan, which require 
Table 3: Reproductive conditions and habitat characteristics of four major Chinese carp and Chinese sturgeon

\begin{tabular}{|c|c|c|c|c|c|c|c|}
\hline & Species & $\begin{array}{l}\text { Spawning } \\
\text { season }\end{array}$ & $\begin{array}{l}\text { Duration } \\
\text { from } \\
\text { fertilization to } \\
\text { hatching }\end{array}$ & $\begin{array}{l}\text { Spawning } \\
\text { temperature } \\
\left({ }^{\circ} \mathrm{C}\right)\end{array}$ & $\begin{array}{l}\text { Singal for } \\
\text { spawning }\end{array}$ & $\begin{array}{l}\text { Environmental } \\
\text { conditions for } \\
\text { spawning }\end{array}$ & Habitat \\
\hline & $\begin{array}{l}\text { Mylopharyngodon } \\
\text { Piceus (Richardson) }\end{array}$ & May-July & $35 \mathrm{~h}\left(21-24^{\circ} \mathrm{C}\right)$ & $\geq 20$ & & & \\
\hline $\begin{array}{l}F \\
M\end{array}$ & $\begin{array}{l}\text { Ctenonpharyngodon } \\
\text { idellus (Cuvier et } \\
\text { Valenciennes) }\end{array}$ & April-July & $35-40 \mathrm{~h}\left(19-21^{\circ} \mathrm{C}\right)$ & $\geq 18$ & $\begin{array}{l}\text { Rising water level } \\
\text { and increasing }\end{array}$ & $\begin{array}{l}\text { Turbulent } \\
\text { flow, mingled } \\
\text { whirlpool current }\end{array}$ & $\begin{array}{l}\text { Middle reach } \\
\text { Chongqing-Pengze } \\
\text { Yichang -Chenglingji }\end{array}$ \\
\hline $\begin{array}{l}\text { C } \\
\text { C }\end{array}$ & $\begin{array}{l}\text { Hypophthalmichthys } \\
\text { molitrix (Cuvier et } \\
\text { Valenciennes) }\end{array}$ & April-July & $35 \mathrm{~h}\left(20-23^{\circ} \mathrm{C}\right)$ & $\geq 18$ & & $\begin{array}{l}\text { flow velocity } \\
0.33-0.90 \mathrm{~m} / \mathrm{s}\end{array}$ & and flow velocity \\
\hline CS & $\begin{array}{l}\text { Aristichthys nobilis } \\
\text { (Richardson) }\end{array}$ & $\begin{array}{l}\text { May-July } \\
\text { April-June }\end{array}$ & $\begin{array}{l}40 \mathrm{~h}\left(19-21^{\circ} \mathrm{C}\right) \\
123-140 \mathrm{~h}\left(17-18^{\circ} \mathrm{C}\right)\end{array}$ & $\begin{array}{l}\geq 18 \\
18-20.5\end{array}$ & $\begin{array}{l}\text { Rising water level } \\
\text { and increasing } \\
\text { flow velocity }\end{array}$ & $\begin{array}{l}\text { Turbulent flow, } \\
\text { mingled whirlpool } \\
\text { current and flow } \\
\text { velocity } 2.2-2.6 \mathrm{~m} / \mathrm{s}\end{array}$ & $\begin{array}{l}\text { Lower reaches of } \\
\text { the Jinsha River } \\
\text { upper reaches of } \\
\text { the Yangtze River } \\
\text { Qingshan Yichang } \\
\text { River section }\end{array}$ \\
\hline
\end{tabular}

*Species; FMCC (Four Major Chinese carps); CS (Chinese sturgeon).

Table 4: Reservoir ecological operation research findings, theory application, and theory building

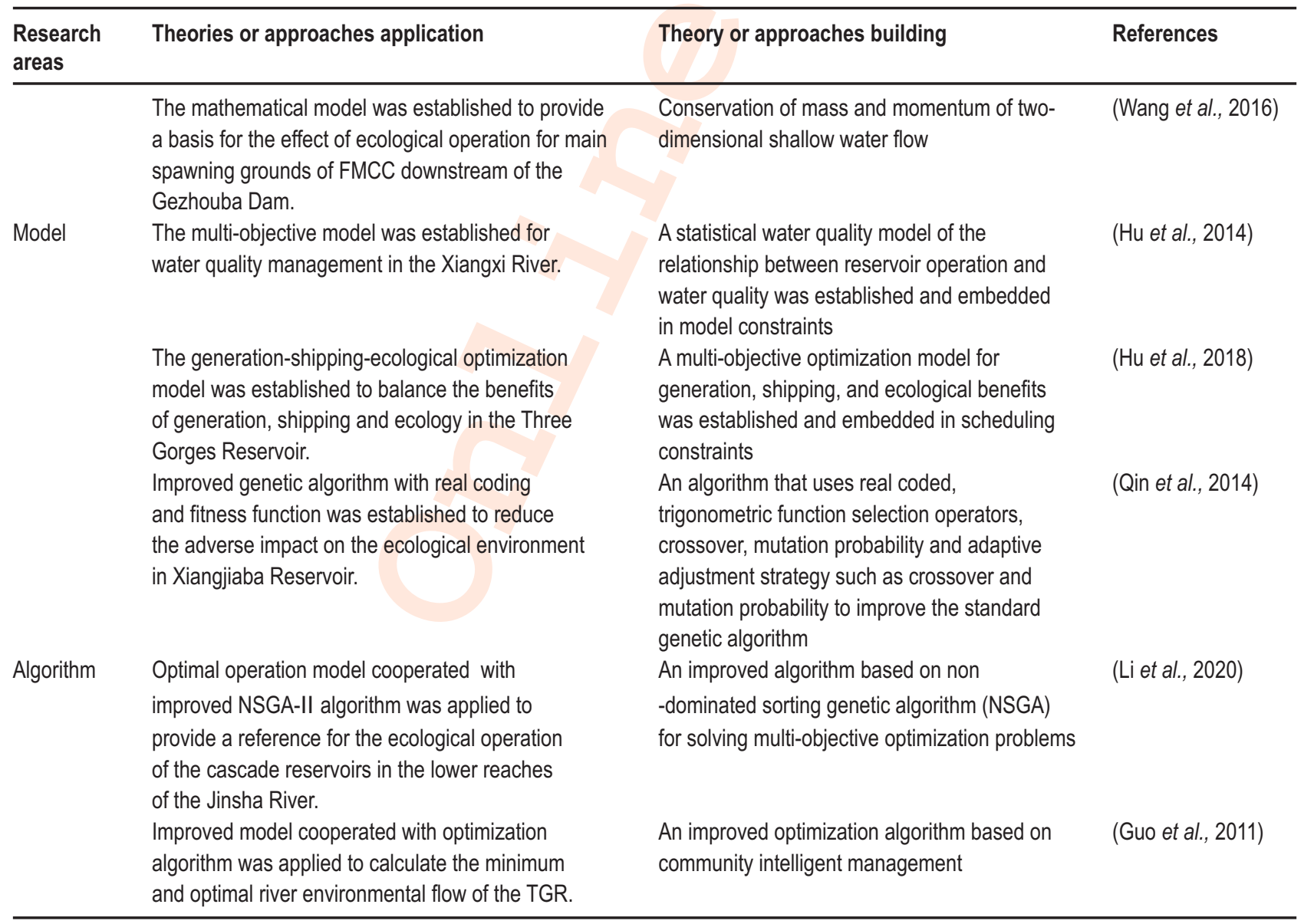


water quality protection, sediment deposition, oxygen saturation, saltwater intrusion and other objectives should be included in the operation (Hakimi-Asiabar et al., 2010). In addition, multi-reservoir joint operation has obviously become another development trend of reservoir ecological operation, in which the balance between economic interests and environmental protection was the key issue (Ding et al., 2020). In published article, the feasibility, economic and environmental benefits of joint operation of Xiluodu dam, Xiangjiaba, and TGR located in the same area were considered (Xu et al., 2008). However, key technologies of water ecological operation for reservoir groups and the impact of reservoir operation on water ecological environment should be further strengthened, which would provide useful information for multi-reservoir operation research. The operation of cascade reservoir involved different stakeholders, so it was necessary to establish a unified negotiation and operation platform to reasonably adjust the interests of different management departments.

The research and application of multi-objective and multispecies ecological operation schedule and models would be another direction of reservoir ecological joint operation, in which the selection of parameters should not only include water quality and flow index. Topography, water level, and biological relationship should be considered to establish more meaningful methods. In addition, ideal physical model is important for seeking optimal ecological operation schemes in some complex hydraulic projects. The existing model studies only carried out simple combined calculation for various operational objectives, while did not consider the superposition effect among various factors systematically, in which uncertainty models can be used sometimes to deal with the computation of environmental information. (Hu et al., 2014). This review article presents status of fish ecosystems and advances of ecological operation published along Yangtze River in the last 20 years and developed a foundation for advancing reservoirs ecological operation research in China by classifying and summarizing different topics, data and contributions. Hydrological factors, Habitats, Species Distribution, Cascade Operation, Multi-Objective Operation and Theoretical Basis are six most prominent research areas related to fish ecosystem and ecological operation in the past 20 years.

To alleviate the negative impact of water conservancy projects, researches that apply existing theories or approaches to multi-objective joint operation, cascade reservoir operation, and model coupling have gradually increased. The multi-objective model has been gradually applied to the study of reservoir ecological operation, and its parameters are more related to multiple objectives, rather than a single index. This review presents an overview of previous articles about the Yangtze river and provide several areas for future research on the reservoir ecological operation.

\section{Acknowledgments}

This study was supported by National Natural Science Foundation of China (51769015; 51879128), Jiangxi Provincial
Technology Department (20202BBGL73094, 20182BCB22013), Jiangxi Provincial Education Department (GJJ180927), Jiangxi Provincial Department of Transportation (2019C0003), Graduate Innovation Program of Nanchang Institute of Technolog (YJSCX202001; YJSCX202002) and Graduate Innovation Program of Jiangxi Province (YC2020-s631; YC2020-S628).

\section{Add-on Information}

Authors' contribution: Jie Zhang: Conceptualization, Methodology, Investigation, Supervision; Yue Zhang: Validation, Visualization, Writing Original Draft; Yingying Feng: Investigation, data analysis; Ruyu Yan: Resources, Data Curation; Yanping Shi: Resources, Writing - Review \& Editing; Yi Zhang: Writing - Review \& Editing; Yong Ji: Review \& Editing, Supervision.

Research content: The research content of manuscript is original and has not been published elsewhere.

\section{Ethical approval: Notapplicable}

The authors declare that there is no conflict of interest.

Data from other sources: Not applicable

Consent to publish: All authors agree to publish the paper in Journal of Environmental Biology.

\section{References}

Aarts, B.G.W., F.W.B.V.D. Brink and P.H. Nienhuis: Habitat loss as the main cause of slow recovery of fish faunas of regulated large rivers in Europe: The transversal floodplain gradient. River Res. Applic., 20, 3-23 (2010)

Bing, H., Y. Wu, J. Zhou, H. Sun, X. Wang and H. Zhu: Spatial variation of heavy metal contamination in the riparian sediments after two-year flow regulation in the Three Gorges Reservoir, China. Sci. Total Environ., 649, 1004-1016 (2019).

Black, A.R., J.S. Rowan, R.W. Duck, O.M. Bragg and B.E. Clelland: DHRAM: A method for classifying river flow regime alterations for the EC Water Framework Directive. Aqua. Conser. Marine FreshwaterEcosys., 15, 427-446 (2005).

Caissie, D.: The thermal regime of rivers: A review. Freshwater Biol., 51, 1389-1406 (2006).

Chang, L.C., F.J. Chang, K.W. Wang and S.Y. Dai: Constrained genetic algorithms for optimizing multi-use reservoir operation. J. Hydrol., 390, 66-74 (2010).

Chang, T., X. Gao, P.D. Danley, P. Lin, M. Li and H. Liu: Longitudinal and temporal water temperature patterns in the Yangtze River and its influence on spawning of the Chinese sturgeon (Acipenser sinensis Gray 1835). River Res. Applica., 33, 1445-1451 (2017).

Chen, D., R. Li, Q. Chen and D. Cai: Deriving optimal daily reservoir operation scheme with consideration of downstream ecological hydrograph through a time-nested approach. Water Res. Manage., 29, 3371-3386 (2015).

Chen, M., X. Qin, G. Zeng and J. Li: Impacts of human activity modes and climate on heavy metal "spread" in groundwater are biased. Chemosphere, 152, 439-445(2016). 
Chong, L.I., J. Peng and W.G. Liao: Study on the eco-hydrological factors and flow regime requirement on spawning of four major Chinese carps in the middle reaches of Yangtze River. J. China Institute WaterResou. Hydrop. Res., 14, 170-176 (2006).

Dai, L., P. Zhang, Y. Wang, D. Jiang, H. Dai, J. Mao and M. Wang: Multiobjective optimization of cascade reservoirs using NSGA-ll: A case study of the Three Gorges-Gezhouba cascade reservoirs in the middle Yangtze River, China. Human Ecol. Risk Asses.: A Int. J., 23, 814-835 (2017).

Deng, W., X. Yuan, H. Liu, Y. Zhang and B. Li: Influence of regional climate change on vegetation cover in the middle and lower Yangtze River basin. Res. Environ. Sci., 27, 1032-1042 (2014).

Ding, Z., G. Fang, X. Wen, Q. Tan, X. Lei, Z. Liu and X. Huang: Cascaded hydropower operation chart optimization balancing overall ecological benefits and ecological conservation in hydrological extremes under climate change. Water Resour. Manage., 34, 1231-1246 (2020).

Du, H., Q.W. Wei, H. Zhang, Z. Liu, C. Wang and Y. Li: Bottom substrate attributes relative to bedform morphology of spawning site of Chinese sturgeon Acipenser sinensis below the Gezhouba dam. J. Appli. Ichthyol., 27, 257-262 (2011).

Duan, W., S. Guo, J. Wang and D. Liu: Impact of cascaded reservoirs group on flow regime in the middle and lower reaches of the Yangtze River. Water, 8, 218-218 (2016).

Ellis, L.E. and N.E. Jones: Longitudinal trends in regulated rivers: A review and synthesis within the context of the serial discontinuity concept. Environ. Revi., 21, 136-148 (2013).

Fan, L.I., Z.Q. Xia and Y.K. Wang: Influence of Gezhouba Project on hydrological and hydraulic characteristics of Yichang river reach. J. Hohai Univer., 38, 36-40 (2010).

Fu, C., J. Wu, J. Chen, Q. Wu and G. Lei: Freshwater fish biodiversity in the Yangtze River basin of China: Patterns, threats and conservation. Biodive. Conserv., 12, 1649-1685 (2003).

Fu, C., J, Wu, X. Wang and L.J. Chen: Patterns of diversity, altitudinal range and body size among freshwater fishes in the Yangtze River Basin, China. Global Ecol. Biogeogr., 13, 543-552 (2004).

Gao, Y., J. Jia, Y. Liu, X. Sun, X. Wen, N. He and T. Yang: Progress in watershed geography in the Yangtze River Basin and the affiliated ecological security perspective in the past 20 years, China. J. Geogra. Sci., 30, 867-880 (2020).

Gillette, D.P., J.S. Tiemann and E.M.L. Wildhaber: Spatiotemporal patterns of fish assemblage structure in a river impounded by lowhead dams. Copeia, 2005, 539-549 (2005).

Guisan, A and W. Thuiller: Predicting species distribution: Offering more than simple habitat models. Ecol. Lett., 8, 993-1009 (2005).

Guo, W.X., H.X. Wang, J.X. Xu and Z.Q. Xia: Ecological operation for three gorges reservoir. Water Sci. Enginee., 4, 143-156 (2011).

Hakimi-Asiabar, M., S.H. Ghodsypour and R. Kerachian: Deriving operating policies for multi-objective reservoir systems: Application of self-Learning genetic algorithm. Appli. Soft Compu., 10, 1151-1163 (2010)

He, S., C. Yu, Z. Xu and Z. Yang: Quantifying parameter uncertainty in reservoir operation associated with environmental flow management. J. Clea. Produc., 176, 1271-1282 (2018).

He, Y., J. Wang, S. Lek-Ang and S. Lek: Predicting assemblages and species richness of endemic fish in the upper Yangtze River. Sci. Total Environ., 408, 4211-4220 (2010).

Houze, R.A.: Orographic effects on precipitating clouds. Reviews of Geophysics., 50, 1-47 (2012).

Hu, M., G.H. Huang, W. Sun, Y. Li, X. Ding, C. An, X. Zhang and T. Li: Multi-objective ecological reservoir operation based on water quality response models and improved genetic algorithm: A case study in Three Gorges Reservoir, China. Enginee. Applic. Artificial Intellige., 36, 323-346 (2014).

Hu, W., S. Zhai, Z. Zhu and H. Han: Impacts of the Yangtze River water transfer on the restoration of Lake Taihu. Ecol. Enginee., 34, 30-49 (2008).

Hu, X., X. Wang, F. Chen and S. Yu: A research on multi-objective generation optimization scheduling of the TGC reservoirs considering ecological and shipping benefits. IOP Conference Series: Materials Science and Engineering. IOP Publishing., pp. 012009 (2018).

Huang, L. and J. Li: Status of freshwater fish biodiversity in the Yangtze River Basin. In: Aquatic biodiversity conservation and ecosystem services. $2^{\text {nd }}$ Edn., Springer-Verlag, China, pp. 13-30 (2016).

Huang, G. and P. Xie: Changes in the structure of fish community with the analysis on the possible reasons in Lake Donghu, Wuhan. Acta Hydrobiol. Sinica., 20, 38-46 (1996).

Humphrey, C.L., D.P. Faith and P.L. Dostine: Baseline requirements for assessment of mining impact using biological monitoring. Austral Ecol., 20, 150-166 (2010).

Jager, H.I. and B.T. Smith: Sustainable reservoir operation: Can we generate hydropower and preserve ecosystem values? River Res. Applica., 24, 340-352 (2010).

Ji, Y., C. Bai, J. Zhang, L. Zhang and X. Huang: Study of water resources carrying capacity in typical counties of Xinjiang Riverbasin, Poyang Lake. J. Jiangxi. Norm. U. (Nat Sci)., 38, 656-660(2014).

Ji, Y., G. Lu, C. Wang, W. Song and H. Wu: Fish transplantation and stress-related biomarkers as useful tools for assessing water quality. J. Environ. Sci., 22, 1826-1832(2010).

Ji, Y.,J. Zhang, Q. Yao and D.H. Zhao: Analysis of water quality in shallow lakes with a Mo-dimensional flow-sediment model. J. Hydrodyn., 19,501-508 (2007).

Ji, Y., X. Xu, J. Wan and S. Hu: Research on simulation of diversion flood routing for Kangshang flood storage in Poyang lake region. Procedia Eng., 28, 740-743 (2012).

Ji, Y., J. Zhang, X.P. Huang, C.R. Bai and X. Chen: Investigation and assessment of heavy metals in surface sediments of Ganjiang River, China. J. Environ. Biol., 35, 1173-1179 (2014).

Ji, Y., J. Zhang, C.R. Bai, W.B. Zhu, G.T. Cai, L. Hu and G.Q. Gao: Distribution characteristics of heavy metals in flood plains, farm fields and high lands in Lake Poyang region in China. J. Environ. Biol., 38, 1301-1311 (2017).

Ji, Y., J. Zhang, L.W. Zhang, X.L. Li, D.D. Wu, J.L. Liu and J. Li: Analysis of heavy metals in the surface sediments of shallow lakes in Nanjishan (Poyang Lake) Natural Wetland in China. J. Environ. Biol., 38, 561-570 (2017).

Ji, Y., J. Zhang, X.L. Li, Y.W. Peng, G.T. Cai, G.Q. Gao, J.Q. Wu and J.L. Liu: Biomarkers responses of rice plants growing in the potentially toxic elements polluted region: A case study in the Le'An Region. Chemosphere, 187, 97-105(2017).

Ji, Y., J. Zhang, H. Zhang, X.C. Liu, N.C. Wu and G.T. Cai: Review on hotspots, challenges and the future of river management strategies in China. J. Environ. Biol., 41, 13-22 (2020).

Jiang, H., S.G. Xie, W.Q. Zhao and J. Chang: Changes of fish assemblages after construction of Ertan Reservior in Yalongjiang River. Acta Hydrobiol. Sinica, 31, 532-539 (2007).

Jury, M.R.: Environmental influences on South African Fish Catch: South coast transition. Int. J. Oceanogr., 2011, 1-10 (2012).

Krawczyk, A.C.D.D.B., L.T. Baldan, J.M.R. Aranha, M.S.D. Menezes and C.V. Almeida: The invertebrate's community in adjacent Alto Iguau's anthropic lakes of different environmental factors. Biota Neotrop., 13, 47-60 (2013).

Kynard, B., Q.W. Wei and F.E. Ke: Use of ultrasonic telemetry to locate the spawning area of Chinese sturgeons. Chinese Sci. Bull., 40, 
668-668(1995).

Li, J.L., J.Y. Tan, J. Wei and B.L. Shi: Water quality at inlet an doutet of the Three Gorges Reservoir and its relation to hydrological regimen and poltants emissions. Ecol. Environ. Monto. Three Gorg., 2, 44$51(2017)$

Li, L., J.Z. Zhou, L. Dai and H.Y. Zhou: Study on multi-objective ecological operation of cascade reservoirs in the lower reaches of Jinshajiang River during impoundment period. Hydrop. Sci., 38, 62-66 (2020) (in Chinese)

Li, Q., M. Yu, G. Lu, T. Cai, X. Bai and Z. Xia: Impacts of the Gezhouba and Three Gorges reservoirs on the sediment regime in the Yangtze River, China. J. Hydrol., 403, 224-233 (2011).

Lin, P.: Current situation and planning of fish biodiversity in the upper Yangtze River basin in the context of hydropower development. Acta Hydrobiol. Sinica., 43, 1-14 (2019).

Liu, S.P., S.L. Qiu, D.Q. Chen and M.G. Huang: Protection and rational utilization of the germplasm resources of the four major Chinese carps in the Yangtze River system. Pesour. Enuiron. Yang. Vall., 6 , 127-131 (1997).

Liu, $\mathrm{X}$. and $\mathrm{H}$. Wang: Estimation of minimum area requirement of river-connected lakes for fish diversity conservation in the Yangtze River floodplain. Diver. Distribu., 16, 932-940 (2010).

Lu, D.: Conservation of the Yangtza River and sustainable development of the Yangtze River Economic Belt. Acta Geograp. Sinica, 73, 1829-1836 (2018).

LV, P.Y. and W.J. Mi: Analysis on general variaton of water quality in Chonging reach after impoundment of Three Gorges Reservoir. Yang. River, 42, 28-32 (2011).

Ma, Q., R. Li, J. Feng, J. Lu and Q. Zhou: Cumulative effects of cascade hydropower stations on total dissolved gas supersaturation. Environ. Sci. Pollu. Res., 25, 13536-13547 (2018).

Mao, Z.P., Y.C. Wang, W.Q. Peng and H.D. Zhou:Advances in effects of dams on river ecosystem. Adv. Water Sci., 16, 134-140 (2005).

Mathews, R. and B.D. Richter: Application of the Indicators of hydrologic alteration software in environmental flow setting1. J. Ameri. Water Resour. Associ., 43, 1400-1413 (2010).

Morita, K. and S. Yamamoto: Effects of habitat fragmentation by damming on the persistence of stream and welling charr populations. Conserv. Biol., 16, 1318-1323 (2002).

Palmer, M.A., H.L. Menninger and E. Bernhardt: River restoration, habitat heterogeneity and biodiversity: A failure of theory or practice? FreshwaterBiol., 55, 205-222 (2010).

Park, Y.S., G. Grenouillet, B. Esperance and S. Lek: Stream fish assemblages and basin land cover in a river network. Sci. Total Environ., 365, 140-153 (2006).

Park, Y.S., J. Chang, S. Lek, W. Cao and S. Brosse: Conservation strategies for endemic fish species threatened by the three gorges dam. Conserv. Biol., 17, 1748-1758 (2003).

Poff, N.L and J.K.H. Zimmerman: Ecological responses to altered flow regimes: a literature review to inform the science and management of environmental flows. Freshwater Biol., 55, 194-205 (2010).

Qiao, Y., X. Tang, S. Brosse and J. Chang: Chinese sturgeon (Acipenser sinensis) in the Yangtze River: A hydroacoustic assessment of fish location and abundance on the last spawning ground. J. Appl. Ichthyol., 22 (Supplement s1), 140-144 (2006).

Qin, M., Y. Peng and X.L. Yu: Xiangjiaba Reservoir ecological operation preliminary study based on genetic algorithm. Advan. Mater. Res., 1010-1012, 1037-1041 (2014).

Shen, Y.X., P.F. Wang, C. Wang, Y. Yang and N. Kong: Potential causes of habitat degradation and spawning time delay of the Chinese sturgeon (Acipenser sinensis). Ecol. Inform., 43, 96-105 (2018).

Shen, Z.Y., L. Chen and T. Chen: Analysis of parameter uncertainty in hydrological and sediment modeling using GLUE method: A case study of SWAT model applied to Three Gorges Reservoir Region, China. Hydrol. Earth Syst. Sci., 16, 121-132 (2012).

Tao, J.P., Y.T. Gong, X.C. Tan, Z. Yang and J.B. Chang: Spatio temporal patterns of the fish assemblages downstream of the Gezhouba Dam on the Yangtze River. Sci. China Life Sci., 55, 626-636 (2012).

Walling, D. and D. Fang: Recent trends in the suspended sediment loads of the world's rivers. Global Plane. Chan., 39, 111-126 (2003).

Wang, C., B. Kynard, Q. Wei, H. Du and H. Zhang: Spatial distribution and habitat suitability indices for non-spawning and spawning adult Chinese sturgeons below Gezhouba Dam, Yangtze River: Effects of river alterations. J. Appl. Ichthyol., 29, 31-40 (2013).

Wang, C., X. Wang, J. Zhou and C. Zhang: The ecological optimization dispatch of the Three Gorges reservoir considering aquatic organism protection. Int. Confer. Control Autom. Robo., pp. 204$208(2015)$

Wang, D., J. Miao and Z. Tan: Impacts of topography and land cover change on thunderstorm over the Huangshan (Yellow Mountain) area of China. Nat. Haza., 67, 675-699 (2013).

Wang, S. and Y. Xie: China Species Red List. Vol II Vertebrates-Part1. $1^{\text {st }}$ Edn., Higher Education Press, China (2009).

Wang, X.H., J.A. Shao, J.L. Wang, D. Wang, J.P. Ni and D.T. Xie: Water quality assessment and its changing trends in the reservoir inflow and outflow along the Yangtze River main stream in the Three Gorge Reservoir Area. Acta Sci. Circumst., 37, 554-565 (2017).

Wang, Y., Z. Xia and D. Wang: A transitional region concept for assessing the effects of reservoirs on river habitats: A case of Yangtze River, China. Ecohydrology, 5, 28-35 (2012).

Wang, Y., M.J. Tang and H.C. Dai: Analysis on correlation between suitability of spawning habitat for four major Chinese carps and discharge from dam. Water Resour. Hydr. Eng., 47, 107-112 (2016).

Wang, Y., N. Zhang, D. Wang, J. Wu and X. Zhang: Investigating the impacts of cascade hydropower development on the natural flow regime in the Yangtze River, China. Sci. Total Environ., 624, $1187-$ 1194 (2018).

Wei, Q., J. Zhang, P. Zhuang, J. Luo, R. Zhou and W. Yang: Biology, fisheries and conservation of sturgeons and paddlefish in China. Environ. Biol. Fishes, 48, 241-255 (1997).

Wu, H.P., J. Chen, J.J. Xu, G.M. Zeng, L.H. Sang, Q. Liu, Z.J. Yin, J. Dai, D.C. Yin, J. Liang and S.J. Ye: Effects of dam construction on biodiversity: Areview. J. Clea. Produ., 221, 480-489 (2019).

Wu, L., T. Bai and Q. Huang: Tradeoff analysis between economic and ecological benefits of the inter basin water transfer project under changing environment and its operation rules. J. Clea. Produ., 248, 119294 (2020).

Wu, X., C. Wei, X. Shen and M. Yang: Reservoir ecological operation research, practice and prospect. Yell. River, 38, 87-90 (2016)

Xu, J.J, J. Chen, Z.J. Yin, G.C. Chen, C.H. Yang and L.Y. Dong: Key issues in the joint operation of large cascade reservoirs in Yangtze River basin. J. Yangtze River Sci. Res. Instit., 25, 1-5 (2008)

Xie, P.: Biodiversity crisis in the Yangtze River: The culprit was dams, followed by overfishing. J. Lake Sci., 29, 1279-1299 (2017).

Yang, D.G., B. Kynard, Q.W. Wei, X.H. Chen, W. Zheng and H. Du: Distribution and movement of Chinese sturgeon, Acipenser sinensis, on the spawning ground located below the Gezhouba Dam during spawning seasons. J. Appl. Ichthyol., 22, 145-151 (2006).

Yang, S.L., J. Zhang and X.J. Xu: Influence of the Three Gorges Dam on downstream delivery of sediment and its environmental implications, Yangtze River. Geophy. Res. Lett., 34, 1-5 (2007). 
Ye, B., D. Yang, T. Zhang, Y. Zhang and Z. Zhou: Hydrological process change with air temperature over the Lena Basin in Siberia. IAHSAISH Publication, 346, 33-38 (2011).

Ye, S.: Studies on fish communities and trophic network model of shallow lakes along the middle reach of the Yangtze River. Institute of Hydrobiology., Chinese Academy of Sciences (in Chinese with English abstract) (2007).

Ye, S., Z. Li, T. Zhang, J. Liu and S. Xie: Assessing fish distribution and threats to fish biodiversity in the Yangtze River Basin, China. Ichthyol. Res., 61, 183-188 (2014).

Yi, Y.J., H.X. Liu and Z.F. Yang: Integrated ecosystem services-based calculation of ecological water demand for a macrophytedominated shallow lake. Global Ecol. Conser., 21, e00858 (2020).

Yi, Y., Z. Yang and S. Zhang: Ecological influence of dam construction and river-lake connectivity on migration fish habitat in the Yangtze River basin, China. Proce. Environ. Sci., 2, 1942-1954 (2010).

Yu, M., D. Yang, X. Liu, Q. Li and G. Wang: Potential impact of a largescale cascade reservoir on the spawning conditions of critical species in the Yangtze River, China. Water, 11, 2027 (2019).

Yu, X.G.: Economic significance of eco-environmental protection and the delineation of ecological functional zones in Yangtze River valley. Resour. Environ. Yang. Basin, 11, 323-326 (2002).

Zhang, H., M. Kang, J. Wu, C. Wang and Q. Wei: Increasing river temperature shifts impact the Yangtze Ecosystem: Evidence from the endangered Chinese sturgeon. Animals, 9, 583 (2019).

Zhang, J., L. Han, Y. Ji, J. Wei, G.T. Cai, G.Q. Gao, J.Q. Wu and Z.D. Yao: Heavy metal investigation and risk assessment along the Le'An River from non-ferrous metal mining and smelting activities in Poyang, China. J. Environ. Biol., 39, 536-545 (2018).

Zhao, Y.: Numerical investigation of a localized extremely heavy rainfall event in complex topographic area during midsummer. Atmosph. Res., 113, 22-39 (2012).

Zhuo, H.H., Z. W. Sun, H.Y. Zheng, W.X. Liu, Y. L. Wu and J. Lan:Analysis on source and variation trends of pollutants in Three Gorges Reservoir. Yang. River, 48, 13-18 (2017). 